\title{
Integrity, stability and management of protection forests in the European Alps
}

\author{
Luuk K.A. Dorren ${ }^{\mathrm{a},}$, Frédéric Berger ${ }^{\mathrm{a}}$, Anton C. Imeson ${ }^{\mathrm{b}}$, \\ Bernhard Maier ${ }^{\mathrm{c}}$, Freddy Rey ${ }^{\mathrm{a}}$ \\ ${ }^{\mathrm{a}}$ Cemagref Grenoble, 2 Rue de la Papeterie, B.P. 76, F-38402 Saint Martin d'Hères Cedex, France \\ ${ }^{\mathrm{b}}$ Institute for Biodiversity and Ecosystem Dynamics_Physical Geography, Universiteit van Amsterdam, \\ Nieuwe Achtergracht 166, 1018 WV Amsterdam, The Netherlands \\ ${ }^{\mathrm{c}}$ Stand Montafon-Forstfonds, Montafonerstraße 21, A-6780 Schruns, Austria
}

Received 4 March 2003; received in revised form 19 January 2004; accepted 20 February 2004

\begin{abstract}
Ecosystem management of protection forests aims at maintaining forests near a state during which effective protection is secured. As the evolution of a dynamic forest ecosystem cannot be stopped, silvicultural measures are required which aim at maintaining both the ecosystem integrity and the protective function of mountain forests. Ecosystem integrity is defined as the system's capacity to maintain structure and ecosystem functions using processes and elements characteristic for its ecoregion. Here, ecosystem functions also reflect the capability of the ecosystem to provide functions of value to humans. Ecosystem integrity of a protection forest implies that the stability (mainly the property resilience is addressed) of the forest is high, because that is required to provide a high level of protection in the long term. The main conditions promoting natural evolutionary processes and ecological stability in protection forests are: (1) a diverse composition of species; (2) sufficient natural regeneration; (3) an optimal forest structure. The first example in this chapter explains how these conditions might be achieved by silvicultural interventions in a forest that mainly protects against rockfall in the Austrian Alps. The second example deals with socio-economic aspects of ecosystem integrity of a forest that also protects against rockfall, but then in the French Alps. Both examples show that forest authorities are aware of techniques to improve the stand stability of protection forests, but the problem is that current forest management is often a kind of trial and error, because the exact consequences of interventions for forest ecosystem dynamics are not known. Therefore, it is proposed that forest ecosystem research should shift focus from protection forest dynamics to the geo-ecosystem functioning of protection forests, including the effects of natural and human disturbances. For this, the concept of panarchy may be a promising way forward.
\end{abstract}

(C) 2004 Elsevier B.V. All rights reserved.

Keywords: Protection forest; Ecosystem integrity; Mountain forest management; Natural hazards; Disturbance; Ecological stability; Geo-ecosystem

\section{Introduction}

The ultimate goal of ecosystem-based management

\footnotetext{
* Corresponding author. Tel.: +33-4-76-76-28-06; fax: +33-4-76-51-38-03.

E-mail address: luuk.dorren@cemagref.fr (L.K.A. Dorren).
} could be summarised as 'the preservation of ecosystem integrity while satisfying human needs' (Grumbine, 1997; Yaffee, 1998; Pirot et al., 2000). Integrity in 
relation to ecosystems was first mentioned by Aldo Leopold who stated 'a thing is right when it tends to preserve integrity, stability and beauty of the biotic community. It is wrong when it tends otherwise' (Leopold, 1949).

Current ecosystem management of forests is mainly based on ecological stability in relation to disturbances. Here, stability is often, for simplicity, characterised by the two components resistance and resilience, or synonyms of these terms (Holling, 1973; Grimm et al., 1992; Larsen, 1995; Führer, 2000; Kräuchi et al., 2000; Motta and Haudemand, 2000; Brang, 2001). Increased knowledge of ecological stability in relation to disturbances and increasing labour costs resulted in a paradigm shift from forest management for timber production towards forest ecosystem management (Attiwill, 1994; Führer, 2000; Harvey et al., 2002), especially in case of management of forests that protect against natural hazards (Larsen, 1995; Brang et al., 2000; Kräuchi et al., 2000; Motta and Haudemand, 2000; Bebi et al., 2001; Brang, 2001). Parallel, it has been discussed whether forest management is necessary at all for ensuring the protective function of a mountain forest on the long term. This argument originates from the view that mountain forests are self-organising stable ecosystems (see Weiss, 2000). Yet, an increasing group of authors report that mountain forests could only fulfil their protective function on the long term if they are managed actively, since instability problems caused by overmaturity arise if silvicultural interventions are absent (Ott, 1978; Ott and Schönbächler, 1986; Führer, 2000; Kräuchi et al., 2000; Motta and Haudemand, 2000; Brang, 2001).

More 'close-to-nature' silvicultural techniques, in comparison to those applied for traditional management of timber production forests, are increasingly applied. Current examples of such methods include minimal tending and the use of stand structural types (Wasser and Frehner, 1996; Motta and Haudemand, 2000; Brang, 2001). The aim of such 'close-to-nature' silvicultural interventions in protection forests is to maintain forest stands in a stage during which effective protection is provided (Motta and Haudemand, 2000). This instantly indicates the main problem of managing protection forests, as it is impossible to stop the evolution of a forest. Therefore silvicultural measures are required, which are associated with the trend of development of the forest ecosystem and which aim at maintaining the integrity of the protection forest ecosystem. To achieve this, knowledge of ecosystem integrity of protection forests is needed. Consequently, the objective of this article is to explain the concept of ecosystem integrity with respect to protection forests and to describe how this concept could be integrated in management of protection forests. We will present two examples dealing with ecological and socio-economic aspects of ecosystem integrity of protection forests in the European Alps. Subsequently, we will discuss some research needs in order to improve ecosystem management of protection forests.

\section{Protection forest: function and dynamics}

First of all, we will give a short description of protection forests as defined in most alpine countries in Europe, since the term is often used for forests with different functions (Ottitsch and Weiss, 2000). Generally, a protection forest has mainly an object-protection or direct protective function (Schönenberger, 2000). At the same time a forest provides a siteprotection function, which is actually a prerequisite for the direct protective function (van Noord, 1996). In addition, like all mountain forests, protection forests provide multiple functions, such as recreation, sequestration of carbon dioxide and conservation of biodiversity (Buttoud, 2000; Cattoi et al., 2000; Führer, 2000; UN-ECE/FAO, 2000).

The direct-protective function of a forest implies that the forest directly protects people, buildings and infrastructure against the impact of natural hazards such as snow avalanches and rockfall (Brang, 2001). The site-protection function is important as a forest stand needs to protect its site against processes such as excessive soil erosion and the occurrence of debris flows (Rey and Chauvin, 2001). If the site-protection function is impaired, the forest site erodes, which results in a loss of the forest ecosystem as a whole.

Mountain forests are self-organising stable ecosystems if regarded at a landscape scale, which normally do not need any silvicultural intervention for their continued existence. But people want to utilise timber as a sustainable resource and therefore need to manage forests. Furthermore, some forests have become degraded as a result of over-harvesting, heavy ungulate browsing or livestock grazing and need to be managed in order to fulfil the protective function. This means that 


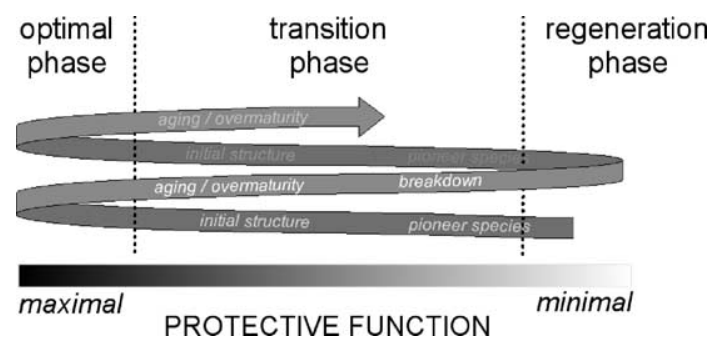

Fig. 1. Developmental phases in mountain forests in relation to the level of protection they provide.

some forests can be left untouched, others can be managed and some need to be managed.

Mountain forest stands constantly evolve from a regeneration phase to an optimal phase and back again, as illustrated in Fig. 1. During the transition phases in between the forest structure develops or breaks down. As a consequence the protective function is minimal during those phases (Motta and Haudemand, 2000), which is also indicated in Fig. 1.

The rate of transition into a next phase is not only determined by growth or ageing of individual trees, but also by the effect of disturbances on the forest ecosystem (Attiwill, 1994; Peterson et al., 2000). A disturbance is a natural or human-induced discrete event in time or space that changes physical (biotic and/or a-biotic) conditions of an ecosystem (after White and Pickett, 1985). The effect of a disturbance is determined by its magnitude and by the ecological stability of the forest stand. Throughout this article we address the property resilience of stability (Grimm and Wissel, 1997). Stability might differ a lot within a stand due to variation in stand factors such as microsite conditions like availability of nutrients, soil moisture and light (Schönenberger, 2000). Therefore, several development phases presented in Fig. 1 may occur simultaneously within a stand. A disturbance might be 'normal' for an ecosystem. Natural disturbances in mountain forests such as snow avalanches or rockfall are important processes since they drive development and change. By doing so, these processes partly determine the integrity of a mountain forest ecosystem.

\section{Forest ecosystem integrity}

Theoretically, a mountain forest that goes through developmental phases without human disturbances consists of the potential natural vegetation characteristic for that ecosystem. The integrity of such an ecosystem is not necessarily high, this depends on the definition of ecosystem integrity. Many scientists discussed ecosystem integrity, especially the last decade (see Karr, 1990; Noss, 1990; Kay, 1991; Woodley et al., 1993; Westra, 1996; De Leo and Levin, 1997; Goldstein, 1998; Müller et al., 2000). Nevertheless, there is still no agreement on a uniform definition. We define ecosystem integrity as the system's capacity to maintain structure and ecosystem functions using processes and elements characteristic for its ecoregion. Here, ecosystem functions do not only refer to relations and processes that are inherently part of a dynamic, open and complex ecosystem (Pimm, 1984; O'Neill et al., 1986). Ecosystem functions also reflect the capability of the ecosystem to support goods and services of value to humans (De Leo and Levin, 1997). Examples are regulation functions, habitat functions, production functions and information functions (after de Groot, 1992). A protection forest is a good example of an ecosystem performing a regulation function.

Since our definition links ecosystem integrity to functions of value to humans, a protection forest ecosystem with a high integrity implies that the stability of the forest is also high, because that is required to provide a high level of protection in the long term. This does not account for a forest without a protective function, since the ecosystem integrity of a forest in a breakdown phase might be high, but the stability is low. A protection forest needs both ecological integrity and stability, since both determine its ecosystem integrity. Ecological integrity is needed to maintain variability in structure and functions; stability is needed to maintain the variability within a critical range. This is essential to avoid perturbation to a state in which the protective function is minimal. Here, perturbation is the change of motion, course, arrangement or structure of a whole ecosystem, caused by disturbances (after White and Pickett, 1985).

\section{Ecosystem management of protection forests}

Within an ecosystem, functions exist which are essential for maintaining its organisation in the face of disturbances. An ecosystem is only capable of providing functions of value to humans if these 
essential functions are fulfilled. Therefore, the primary objective of management strategies is to protect, maintain and/or restore the essential ecosystem functions of forest ecosystems using processes and elements characteristic for its ecoregion (Andersson et al., 2000; Schlaepfer et al., 2002). These characteristics all are related to the ecological integrity of the system. Subsequently, stability with respect to a function of value to humans could be promoted, by e.g. applying 'close-to-nature' silvicultural techniques, to obtain high ecosystem integrity.

The main problem with protection forest management is to predict the trend of development of a forest in the face of disturbances, which could be both human and natural, but especially the natural hazard the forest should protect against. This relatively unknown factor in combination with the given fact that an ecosystem is an open, dynamic system, endorses the general rule stated by Holling and Meffe (1996) that ecosystem management should not aim at preserving something that must change. Consequently, forest ecosystem dynamics must be integrated into management strategies (Attiwill, 1994). Adaptive management is therefore a necessity. Current management of protection forests mainly tends to preserve stand stability, but the aim should be to create or maintain conditions that promote evolutionary processes while maintaining forest ecosystem integrity in relation to its assigned function. Fig. 2 shows that, before silvicultural measures are planned and executed, two important questions need to be answered. The first question is whether the ecological integrity of the protection forest is high. If this is the case, the second question is whether the ecological stability is high. If one of these conditions is not fulfilled, measures could be taken, if considered appropriate, as shown in Fig. 2.

\section{Towards implementation}

Conditions promoting natural evolutionary processes and ecological stability in protection forests could be categorised in three practical and general criteria (modified from Motta and Haudemand, 2000):

1. diverse composition of species;

2. sufficient natural regeneration;

3. optimal forest structure.

But before these criteria are evaluated to estimate the ecosystem integrity of a protection forest, its history must be assessed. The origin of the forest, past silvicultural treatments and evidences of natural disturbances must be known (Motta and Haudemand, 2000). The further management starts from the state defined by the criteria mentioned above, the stronger the management intervention must be (Führer, 2000), but preferably silvicultural intervention mimics

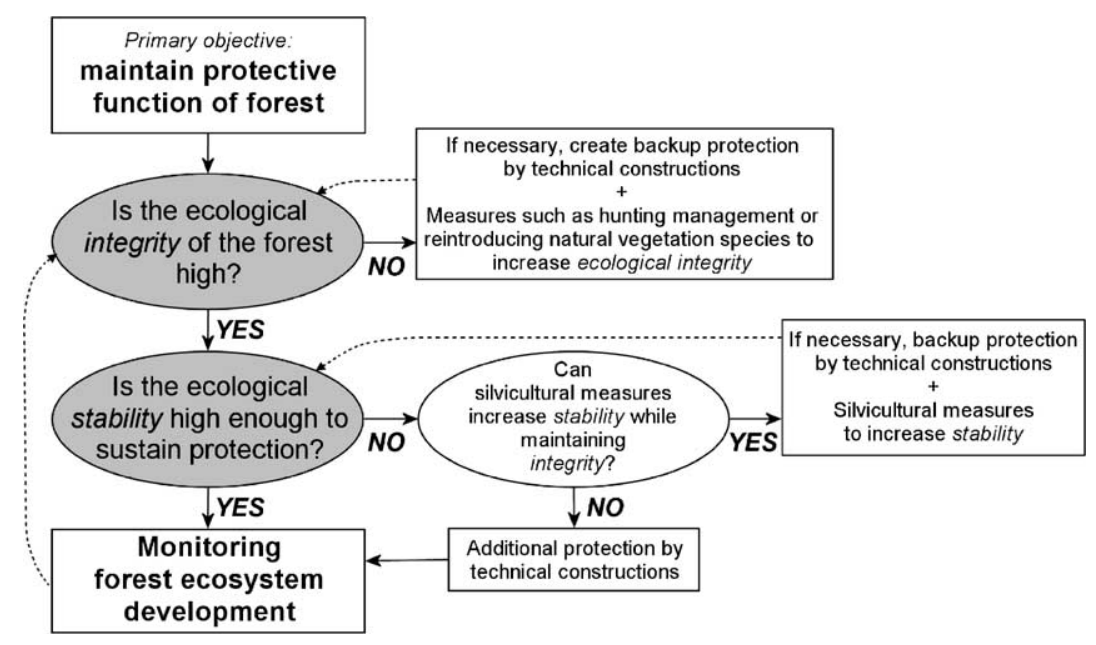

Fig. 2. Flow chart presenting essential steps in determining a management plan for protection forests. Solid arrows indicate direct actions to be taken or questions to be answered and dotted arrows indicate an intermediate time period of several years to decades. 
small-scale natural disturbances (Bengtsson et al., 2000). If ecosystem dynamics tend to deviate from the course directed to fulfilment of the criteria, the suitability of the forest stand for performing a protective function might be questioned. Other protective measures, like technical constructions such as rockfall retaining nets and avalanche barriers, might be required in such a case, since management cannot push a forest ecosystem in a direction opposite to the natural one.

The composition of species should be characteristic for the ecoregion and if possible diverse (both for the trees and the understory vegetation). Diversity determines the amount of variability in the potential drivers of an ecosystem (Holling and Meffe, 1996), which are the key species and key processes in an ecosystem. It is still unclear whether a diverse composition of species increases ecosystem stability (Holling, 1973; May, 1973; Tilman and Downing, 1994; De Leo and Levin, 1997; Tilman et al., 1997; Bengtsson et al., 2000). However, there is much evidence that mixed forests are more resistant to perturbations and more resilient after disturbances than monocultures. It is also thought that they perform ecosystem functions more reliable over time (Larsen, 1995; Bengtsson et al., 2000).

Natural regeneration is equally important as the species composition, because it is the primary source for natural stand renewal. Therefore, the maintenance of a good seedling bank is required, but sufficient light, prevention of competing ground vegetation suppressing seedlings, prevention of heavy browsing by ungulates as well as suitable seedbeds are also important (Ammer, 1996; Motta, 1996; Ott et al., 1997; Fuller and Gill, 2001). Tree stems lying on the slope surface provide both good protection against rockfall and snow avalanches and they provide good seedbeds. Therefore, timber should be left in the stand unless it is too risky with respect to bark beetle infestation (Kräuchi et al., 2000).

The optimal structure of a protection forest depends on the type of natural hazards the forest is protecting against. For example, a forest protecting against rockfall should have a large number of trees, preferably with thick tree stems near the rockfall source area (Wasser and Frehner, 1996). This, however, is related to different developmental stages of a forest stand (regeneration/transtition phase and optimal phase) and therefore, difficult to achieve. The results of our rock- fall experiments in a French mountain forest imply that the number of trees is more important than the diameter of the trees. At the same time a multilayered stand is needed to ensure a certain degree of protection on the long term. In the accumulation zone of a rockfall slope, a forest consisting of dense bushes and shrubs is preferred (Mani and Kläy, 1992; Gsteiger, 1993; Berger and Renaud, 1994; Berger and Rey, 2001). Generally, uneven multilayered stands with a mosaic of all sizes and age classes are the best suited for protection (Ott et al., 1997; Kräuchi et al., 2000; Motta and Haudemand, 2000). This general structure should be aimed for since protection forests mostly protect against several types of natural hazards. The cluster structure, which is characteristic for high-elevation stands, may serve as a model for the arrangement of seedlings in plantations and for silvicultural interventions in homogeneous stands aiming at the optimal structure for protection (Schönenberger, 2001b).

Ideally, a forest ecosystem that fulfils the three general criteria mentioned above enters a 'steadystate' in which small patches with alternating developmental phases provide a collective stability for the stand or forest (see Fig. 3). Führer (2000) assumes that in this state efficient mechanisms of self-regulating processes control all destabilising forces, thus keeping the destructive phases temporally and spatially within ecologically tolerable limits, which is sub-optimal for protection on the short term, but as optimal as possible on the long term.

\section{A silvicultural/forest ecological example}

The 'Ausserbacher' forest covers about 50 ha on a south-southwest facing slope in the Montafon region

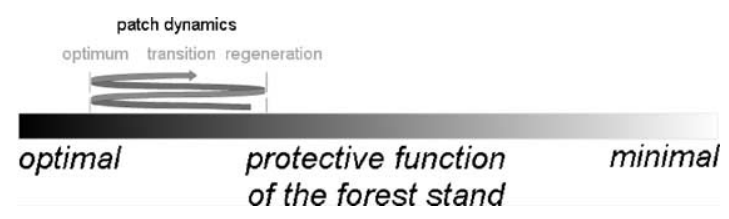

Fig. 3. A sub-optimal protective function could be maintained by small patches in phase-shifted developmental states, which build up a collective stability for the forest stand. This approach requires that similar phases of patch dynamics are not occurring synchronically, e.g. all the patches being in a breakdown phase. 
in Austria (between $46^{\circ} 50^{\prime}$ and $47^{\circ} 8^{\prime}$ latitude and $9^{\circ} 41^{\prime}$ and $10^{\circ} 9^{\prime}$ longitude). The forest stretches from the valley (930 $\mathrm{m}$ a.s.l.), up to $1500 \mathrm{~m}$ a.s.l. and grows on a uniformly shaped talus slope with an average inclination of $39^{\circ}$. Because of its proximity to the Ausserbach hamlet this forest has always been an important resource for local inhabitants in terms of wood production and grazing livestock. Above all, the forest protects the Ausserbach hamlet against falling rocks, which originate from a cliff face, with a height up to $100 \mathrm{~m}$, in the upper part of the forest hillslope. In addition, the forest prevents the release of snow avalanches on the steep parts of the hillslope.

In 1988 the protective function of the forest reached a critical level because firstly most of the trees had been damaged by rockfall while substantial regeneration was lacking and secondly, the forest was prone to wind throw. It seemed that the ecological processes could not sustain the protective function of the forest and as a result, ecosystem integrity could not be maintained. Therefore, the forest authority initiated a restoration project, which started with assessing the history of human and natural disturbances in the forest. This assessment showed that the grazing of sheep until 1960 had a long-term effect on the species composition of the forest. As they feed selectively, natural regeneration of deciduous trees and shrubs in particular, was suppressed. Indicative is that the present coverage of beech (Fagus sylvatica), is not more than $10 \%$, although the potential natural forest community up to an altitude of $1050 \mathrm{~m}$ corresponds to a beech-dominated Luzulo fagetum. After 1960, two feeding stations for ungulates were installed in the forest, which resulted in an enormous browsing pressure for 20 years. This further caused a lack of natural regeneration. In addition to the direct and indirect human interference there has been a permanent impact of natural disturbances such as rockfall, snow avalanches and wind (Dorren et al., 2004).

A map of the developmental stages of the forest, carried out in 1988 according to Leibundgut (1959), showed that $84 \%$ of all the trees in the Ausserbacher forest were damaged by rockfall (Stand Montafon, 1990). About $45 \%$ of the total forest area was in a socalled ageing phase (Fig. 4), which was amongst others indicated by a low tree density of 290 trees/ ha. At first sight these stands appeared stable against wind throw because of the varying horizontal and vertical structure and a well-distributed network of vital long-crowned skeleton trees (in German: Gerüstbäume, being trees with a stabilising function). But the high percentage of trees with heart rot reduced this apparent resistance. Crucial for the future stand development was the lack of regeneration, which would have considerably reduced the resilience of the forest in the long term.

Twenty-two percent of the forest was identified as being in an optimal phase and had an average number of 560 trees/ha. The optimal forest stands were sprucedominated and mainly structured in homogeneous single-layers. In combination with high coefficients of slenderness (length/width ratio), short crown lengths and the high degree of trees damaged by falling rocks, the threat of wind throw would increase in these stands. Only 19\% of the area could be classified as a so-called selection forest with a multilayered structure and a mosaic of ageing, breakdown and regeneration phases. This type of forest grows mainly on steep rocky and blocky sites, because of the diversity in abiotic conditions. The unstocked (denuded of trees) stripes shown in Fig. 4 are attributable to snow gliding and intensive rockfall. In 1988 , these accounted for $14 \%$ of the total area.

On the basis of all the previously described information, the forest authority regarded: (a) the reduction of ungulate population; (b) the improvement of the accessibility via forest roads; (c) the construction of avalanche barriers and rockfall nets in the major rockfall channel as urgent. These measures were a prerequisite for the implementation of the following silvicultural measures:

- small-scale felling with deposition of trees diagonal to the slope direction;

- narrow irregular stripe felling diagonal to the slope direction, using cable cranes;

- reforestation of unstocked forest land and coppicing hazel to stimulate its growth.

The forest authority aimed for a mosaic of stand patches at different developmental stages by splitting the homogeneous optimal and optimal/ageing stands into smaller patches using irregular stripe felling. Once regeneration in these felled stripes has reached a more mature stage, the mosaic-creation process will be continued by additional stripe felling. This process has to be carried out during a whole developmental 


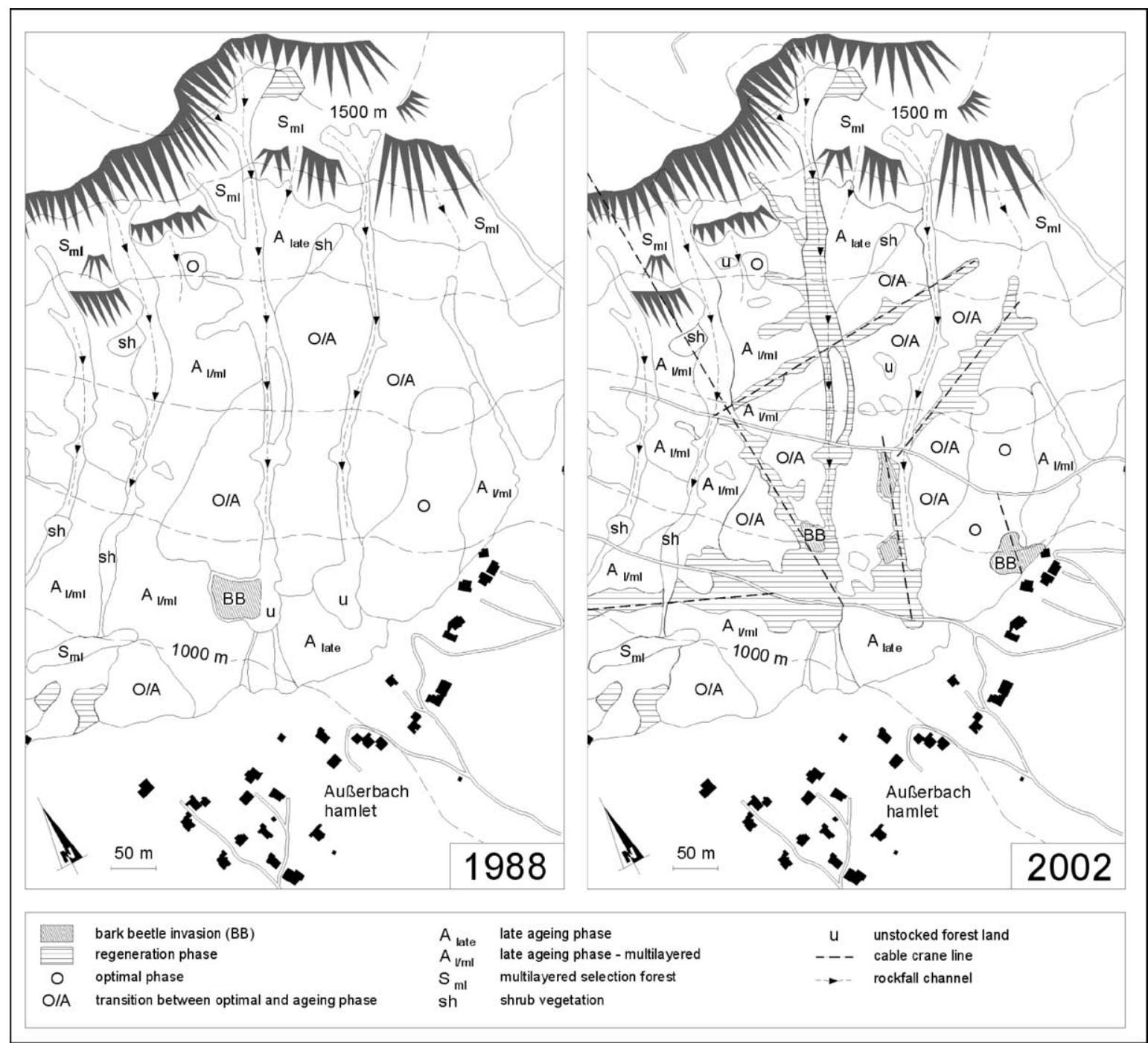

Fig. 4. Distribution of developmental phases, disturbances and silvicultural measures.

cycle of a stand, which takes about 200 years, in order to obtain phase-shifted mosaic structures (see Otto, 1994). Cut stems were left on site and deposited diagonal to the slope direction in order to decelerate and to redirect rockfall. Stems that are deposited perpendicular to the slope direction result in large rock accumulations behind them and possibly in small rock avalanches once the stems have decayed, which takes about 10 years in the study area.

The forest authority observed that in the course of felling activities the vulnerability to bark beetle infes- tation increased due to bark damages, sunburn on the stem, and the attraction of bark beetles by left slush timber. During warm and dry summers this indeed resulted in two subsequent bark beetle invasions (see Fig. 4), but fortunately it was observed that this contributed to the mosaic creation process. When comparing the situation of 1988 and 2002 it can be seen that $15 \%$ of the optimal phase changed into a regeneration phase. Furthermore, 32\% of the unstocked forest land and areas covered with shrubs also showed regeneration (Table 1). 
Table 1

The partition of the different phases in the Ausserbacher forest in 1988 and 2002

\begin{tabular}{lcccc}
\hline Phase & $1988\left(\mathrm{~m}^{2}\right)$ & $1988(\%)$ & $2002\left(\mathrm{~m}^{2}\right)$ & $2002(\%)$ \\
\hline Optimal and optimal/ageing phase & 85506 & 26 & 69865 & 21 \\
Late ageing phase (multilayered) & 101787 & 31 & 92336 & 28 \\
Multilayered selection forest & 92630 & 28 & 92630 & 28 \\
Regeneration & 2853 & 1 & 40626 & 12 \\
Shrub vegetation, unstocked forest land & 49284 & 15 & 36603 & 11 \\
Total & 332060 & 100 & 332060 & 100 \\
\hline
\end{tabular}

\section{A silvicultural/socio-economic example}

The forest of Sainte-Foy Tarentaise (France), which covers $1130 \mathrm{ha}$, is located in the upper valley of the Isère river on steep glacially eroded valley slopes. Half of this forest covers slopes with gradients higher than $30^{\circ}$. The forest occupies an intermediary position between a glacier (Mont Pourri, $3780 \mathrm{~m}$ a.s.l.) and a valley with intense traffic. The valley road leads to the ski resorts of Tignes and Val d'Isère and traffic was estimated at 13000 cars daily in February 1993. Especially the forest in the 'Raie' area, which covers 100 ha with mainly quasi-pure spruce stands, provides protection of roads against rockfall. This forest is located on the steepest side of a southwest oriented slope.

In April 1986, rockfall caused the death of four people, confirming the magnitude of the problem and the need for treatment. The proximity of the Olympic games in Albertville stimulated local authorities to initiate a restoration project. Moreover, the effects of the Viviane windstorm in 1990, which destroyed several hectares of unstable stands, stressed the need for such a project. The first step in the restoration project was an assessment of the risk posed by rockfall using a rockfall trajectory simulation program (Cattiau et al., 1995). Forestry data were derived from a study carried out by Cemagref (Renaud et al., 1994). On the basis of these data, five forest structure types were derived, which were representative for the amount of kinetic energy of falling rocks that could be absorbed by the different forest stands (Cattiau et al., 1995). The model results showed that $60-95 \%$ of all rocks starting from the top would get to the road if the forest stands were absent. The presence of trees, even scarce, reduced the rockfall hazard, either by stopping the rocks before the road or by limiting the height of the rebound, thus increasing the level of protection and reducing the cost of other measures, such as civil engineering based ones. With the forest cover present at the time of investigation, $10-15 \%$ of all the simulated falling rocks would reach the road. Subsequently, several forest cover scenarios were tested and showed that a high level of protection was provided by dense forest stands with a high basal area $\left(>25 \mathrm{~m}^{2} / \mathrm{ha}\right)$, especially if these stands were located near the top of the slope. Less dense stands, but well located in mosaics, were also providing sufficient protection, even though the average stopping distance of falling rocks was longer. In case of an absence of forest cover at the top in combination with dense forest stands at the bottom of the hillslope, most of the rocks reached the road. On the basis of these observations two silvicultural options were discussed:

- establishing relatively homogeneous and dense stands with thick tree stems (DBH of 30-40 cm) or;

- creating a structural mosaic, constituted of a regular alternation between ageing structures with initial regeneration and more dense ones with optimal growth.

The first option is very efficient in stopping rocks, but it also takes a long time, it is unstable and in the long term it needs intensive care to be maintained. The latter option, although less efficient in terms of protection, appears nonetheless better adapted and less risky in the scope of extensive management. This is because the forest structure is more stable and the continuity of functions is better guaranteed. Taking into account the local context and accompanying exploitation problems, the second option was chosen. The objective was to create structural patches of limited sizes (maximal 4-5 acres). The wood was removed by helicopter in order to avoid closing the 
road and dragging wood on the ground, which might destabilise rocks. The total costs were $€ 21000$, the wood was sold for $€ 16400$ and therefore the operating loss was $€ 4600$. The Department of Savoie, fully aware of the importance of this operation for safety, granted the owner of the forest (i.e. the local town) $€$ 15 000. Therefore, net profit for the owner amounted to $€ 10400$. But, without the subsidy given by the Department of Savoie, the described operation would have been cancelled. At present, the forest provides sufficient protection against rockfall, but active management is required to maintain this level of protection. This example shows that a constant dialog between the people working in the forests, the forest managers, and forest researchers is important. In addition, efforts are needed firstly to demonstrate the wider socio-economic importance of adequate management of protection forests to local authorities/governments and secondly to involve them into the management process.

\section{Synthesis: interaction between human and natural systems}

Forest ecosystem integrity is rooted both in ecological as well as in social and economical aspects, as forest ecosystems are expected to provide functions of values or services to humans, which requires ecological stability. A forest is a dynamic system, continually changing in response to natural and human disturbances. Some disturbances help to maintain forest ecosystem integrity, while others threaten it. As shown by the example in the Austrian Alps, forest management interventions were required to restore the integrity of protection forests. The loss of integrity was due to the long history of direct and indirect human impact on the forest ecosystem in combination with the natural disturbances as well as the natural biotic processes. This resulted in a situation where silvicultural measures were required. This is an excellent example of a panarchy. A panarchy is a structure in which systems, including those of nature and of humans, as well as combined human-natural systems, are interlinked in continual adaptive cycles of growth, accumulation, restructuring, and renewal (Holling, 2000; Gunderson and Holling, 2002). Panarchy has evolved from hierarchy theory, firstly applied in geo-ecosystem research by Allen and Starr (1982) and O'Neill et al. (1986). They initiated an increase of theoretical understanding by viewing the landscape as a multi-scale dynamic system in which biotic and abiotic processes interact. However, both the adaptive nature of such systems, organised by periodic and transient phases of growth, conservation, collapse and reorganisation and the interaction with human systems has tended to be lost. Therefore, panarchy, a term devised to describe evolving hierarchical systems with multiple interrelated elements, offers an important new framework for understanding and resolving this dilemma. The steering variables in the panarchy of forest that protects against rockfall are the frequency and magnitude of rockfall, growth of individual trees, regeneration and breakdown of the forest as well as silvicultural interventions. These variables are all interacting. At the same time, some of them are the result of an adaptive cycle within themselves. For example, whether or not silvicultural interventions will be carried out in protection forests depends on factors acting in social, economical and to a lesser extent forest ecological systems (see also Buttoud, 2002), as shown by the example in the French Alps.

There is a need for the theoretical framework panarchy provides. The examples show that forest authorities are aware of techniques to improve the stability of protection forest ecosystems, but the problem is that current forest management is often still a kind of trial and error, because the exact consequences of interventions for forest ecosystem dynamics are not known. This accounts both for the impact of the natural hazard the forest should protect against as well as the future dynamics of the forests ecosystem. Despite this knowledge gap, which is due to the lack of research and the fact that previous disturbances affect the development of a forest for a long time, foresters are increasingly aware of the self-organising capacity of forests, which is indicated by the fact that they do take into account natural forest ecosystem processes as far as possible in the silvicultural measures taken. It is known that it is important not to try stopping the 'natural' stand development, but to exploit forest dynamics for silvicultural and overall management objectives. Especially this should be investigated more, as recognised by many authors (Attiwill, 1994; Andersson et al., 2000; Bengtsson et al., 2000; Führer, 2000; Kräuchi et al., 2000; Bebi et al., 
2001; Brang, 2001; Schönenberger, 2001a). Regarding the interaction between forests and natural hazards, research should shift focus to mountain geo-ecosystem functioning. In replication of Troll (1971), Rowe and Barnes (1994) and Huggett (1995) we prefer the term geo-ecosystem to place the emphasis not only on the biosphere, but also on the atmosphere, hydrosphere, lithosphere and pedosphere, which are dynamic and important parts of mountain forest landscapes. Understanding geo-ecosystem functioning differs from assessing how geo-ecosystem functions are performed; it is about understanding how our surrounding dynamic ecosystems, which are affected by our social and economical systems, operate. Therefore, panarchy is a promising way forward to improve ecosystem management of protection forests in mountains and to sustain ecosystem integrity in general. Because if the panarchy of a protection forest would be understood better, different silvicultural interventions could be simulated to test its effect on the integrity of the forest ecosystem. Consequently optimal silvicultural procedures could be pinpointed.

This paper presented two real world examples regarding the management of forests that protect against rockfall. In addition, the theoretical nature of the state-of-the-art concepts of ecosystem management has been described. Overall, this paper indicates a gap between the theory and practice of protection forest management. To help decrease this gap, we focus at the development of a method for obtaining more knowledge about the interaction between abiotic (rockfall) and biotic (protection forest structure) factors in a mountain geo-ecosystem. This method and the obtained knowledge will be another step towards understanding the panarchy of protection forests in mountain geo-ecosystems.

\section{References}

Attiwill, P.M., 1994. The disturbance of forest ecosystems: the ecological basis for conservative management. For. Ecol. Manage. 63 (2), 247-300.

Allen, T.F.H., Starr, T.B., 1982. Hierarchy: Perspectives for Ecological Complexity. University of Chicago Press, Chicago, p. 310.

Ammer, C., 1996. Impacts of ungulates on structure and dynamics of natural regeneration of mixed mountain forests in the Bavarian Alps. For. Ecol. Manage. 88, 43-53.
Andersson, F.O., Feger, K.H., Hüttl, R.F., Kräuchi, N., Mattsson, L., Sallnäs, O., Sjöberg, K., 2000. Forest ecosystem researchpriorities for Europe. For. Ecol. Manage. 132, 111-119.

Bebi, P., Kienast, F., Schönenberger, W., 2001. Assessing structures in mountain forests as a basis for investigating the forests dynamics and protective function. For. Ecol. Manage. 145, 3-14.

Bengtsson, J., Nilsson, S.G., Franc, A., Menozzi, P., 2000. Biodiversity, disturbances, ecosystem function and management of European forests. For. Ecol. Manage. 132, 39-50.

Berger, F., Renaud, J.P., 1994. Stabilité et fonction de protection des forêts de montagne dans les Alpes du Nord. L'exemple de la forêt domaniale de Rioupéroux. Revue Forestière Française 46 (4), 359-374.

Berger, F., Rey, F., 2001. Mountain protection forests against natural hazards and risks: from research to management. In: Proceedings of the International Conference on "Forest Research: A Challenge for an Integrated European Approach". Thessaloniki, Greece, 27 August-1 September 2001, vol. I, pp. 275-280.

Brang, P., Schönenberger, W., Ott, E., 2000. Forests as Protection From Natural Hazards, The Forests Handbook, vol. 2. Blackwell Scientific, Oxford.

Brang, P., 2001. Resistance and elasticity: promising concepts for the management of protection forests in the European Alps. For. Ecol. Manage. 145, 107-117.

Buttoud, G., 2000. Approaches to multifunctionality in mountain forests. In: Price, M.F., Butt, N. (Eds.), Forests in Sustainable Mountain Development: A State of Knowledge Report for 2000. IUFRO Research Series 5. CABI Publishing, Wallingford, UK, pp. 187-193.

Buttoud, G., 2002. Multipurpose management of mountain forests: which approaches? For. Policy Econ. 4 (2), 83-87.

Cattiau, V., Marie, E., Renaud, J.P., 1995. Forêt et protection contre les chutes de rochers. Ingénieries Cemagref Eau-AgricultureTerritoire 3, 45-54.

Cattoi, S., Pollini, C., Tosi, V., 2000. Case study: multifunctionality in the fiemme valley, Italian Alps. In: Price, M.F., Butt, N. (Eds.), Forests In Sustainable Mountain Development: A State of Knowledge Report for 2000. IUFRO Research Series 5. CABI Publishing, Wallingford, UK, pp. 203-205.

De Leo, G.A., Levin, S.A., 1997. The multifaceted aspects of ecosystem integrity. Conservation Ecology 1(1). Available: as seen on December 1st 2001. http://www.consecol.org/vol1/iss1/art3.

Dorren, L.K.A., Maier, B., Putters, U.S., Seijmonsbergen, A.C., 2004. Combining field and modelling techniques to assess rockfall dynamics on a protection forest hillslope in the European Alps. Geomorphology 57 (3-4), 151-167.

Führer, E., 2000. Forest functions, ecosystem stability and management. For. Ecol. Manage. 132, 29-38.

Fuller, R.J., Gill, R.M.A., 2001. Ecological impacts of increasing numbers of deer in British woodland. Forestry 74 (3), 193-199.

Goldstein, P.Z., 1998. Functional ecosystems and biodiversity buzzwords. Conserv. Biol. 13 (2), 247-255.

Grimm, V., Schmidt, E., Wissel, C., 1992. On the application of stability concepts in ecology. Ecol. Model. 63, 143-161.

Grimm, V., Wissel, C., 1997. Babel, or the ecological stability discussions: an inventory and analysis of terminology and a guide for avoiding confusion. Oecologia 109, 323-334. 
de Groot, R.S., 1992. Functions of Nature. Evaluation of Nature in Environmental Planning, Management and Decision Making. Wolters Noordhoff, Deventer, The Netherlands, p. 315.

Grumbine, R.E., 1997. Reflections on "What is ecosystem management?". Conserv. Biol. 11, 41-47.

Gsteiger, P., 1993. Steinschlagschutzwald, Ein Beitrag zur Abgrenzung, Beurteilung und Bewirtschaftung. Schweizerische Zeitschrift für Forstwesen 144, 115-132.

Gunderson, L.H., Holling, C.S., 2002. Panarchy: Understanding Transformations in Human and Natural Systems. Island Press, Washington, DC, pp. 507.

Harvey, B.D., Leduc, A., Gauthier, S., Bergeron, Y., 2002. Stand-landscape integration in natural disturbance-based management of the southern boreal forest. For. Ecol. Manage. 155, 369-385.

Holling, C.S., 1973. Resilience and stability of ecological systems. Ann. Rev. Ecol. Syst. 4, 1-24.

Holling, C.S., Meffe, G.K., 1996. Command and control and the pathology of natural resource management. Conserv. Biol. 10 (2), 328-337.

Holling, C.S., 2000. Theories for sustainable futures. Conserv. Ecol. 4, 7http://www.consecol.org/vol4/iss2/art7..

Huggett, R.J., 1995. Geoecology. An Evolutionary Approach. Routledge, UK, p. 320.

Karr, J.R., 1990. Biological integrity and the goal of environmental legislations: lessons for conservation biology. Conserv. Biol. 4, 244-250.

Kay, J.J., 1991. A non-equilibrium thermodynamic framework for discussing ecosystem integrity. Environ. Manage. 15 (4), 483-495.

Kräuchi, N., Brang, P., Schönenberger, W., 2000. Forests of mountainous regions: gaps in knowledge and research needs. For. Ecol. Manage. 132 (1), 73-82.

Larsen, J.B., 1995. Ecological stability of forests and sustainable silviculture. For. Ecol. Manage. 73, 85-96.

Leibundgut, H., 1959. Über Zweck und Methodik der Struktur- und Zuwachsanalyse von Urwäldern. Schweizerische Zeitschrift für Forstwesen 110, 111-124.

Leopold, A., 1949. A Sand County Almanac and Sketches Here and There. Oxford University Press, NY, p. 228.

Mani, P., Kläy, M., 1992. Naturgefahren an der Rigi-Nordlehne, Die Beurteilung von Naturgefahren als Grundlage für die waldbauliche Massnahmenplanung. Schweizerische Zeitschrift für Forstwesen 143, 131-147.

May, R.M., 1973. Stability and Complexity in Model Ecosystems. Princeton University Press, Princeton, USA.

Motta, R., 1996. Impact of wild ungulates on forest regeneration and tree composition of mountain forests in the western Italian Alps. For. Ecol. Manage. 88, 93-98.

Motta, R., Haudemand, J.C., 2000. Protective forests and silvicultural stability. An example of planning in the Aosta valley. Mountain Res. Dev. 20, 74-81.

Müller, F., Hoffmann-Kroll, R., Wiggering, H., 2000. Indicating ecosystem integrity-theoretical concepts and environmental requirements. Ecol. Model. 130, 13-23.

van Noord, H., 1996. The role of geomorphological information in ecological forest site typology in mountainous areas, a methodological study in the E-Rätikon and NW-Montafon mountains (Vorarlberg, Austria). PhD Thesis. University of Amsterdam, Amsterdam, p. 185.

Noss, R.F., 1990. Can we maintain biological and ecological integrity? Conserv. Biol. 4, 241-243.

O’Neill, R.V., DeAngelis, D.L., Waide, J.B., Allen, T.F.H., 1986. A Hierarchical Concept of Ecosystems. Princeton University Press, Princeton, New Jersey.

Ott, E., 1978. Zur Notwendigkeit der Pflege von Gebirgswäldern. Schweizerische Zeitschrift für Forstwesen 129 (2), 101-116.

Ott, E., Schönbächler, D., 1986. Die Stabilitsbeurteilung im Gebirgswald als Voraussetzung für die Schutzwald-Überwachung und-Pflege. Schweizerische Zeitschrift für Forstwesen 137 (9), 725-738.

Ott, E., Frehner, M., Frey, H., Lüscher, P., 1997. Gebirgsnadelwälder: Ein Praxisorientierter Leitfaden für eine Standortgerechte Waldbehandlung. Paul Haupt Verlag, Bern.

Ottitsch, A., Weiss, G., 2000. European mountain forest policiesa comparative analysis. In: Price, M.F., Butt, N. (Eds.), Forests in Sustainable Mountain Development: A State of Knowledge Report for 2000. IUFRO Research Series 5. CABI Publishing, Wallingford, UK, pp. 415-421.

Otto, H.J., 1994. Waldökologie. Verlag Eugen Ulmer, Stuttgart, p. 391.

Peterson, D.L., Prichard, S.J., McKenzie, D., 2000. Disturbance in mountain forests. In: Price, M.F., Butt, N. (Eds.), Forests in Sustainable Mountain Development: A State of Knowledge Report for 2000. Task Force on Forests in Sustainable Mountain Development. CABI Publishing, pp. 51-58.

Pimm, S.L., 1984. The complexity and stability of ecosystems. Nature 307, 321-326.

Pirot, J.-Y., Meynell, P.J., Elder, D., 2000. Ecosystem management: lessons from around the world. A guide for Development and Conservation Practitioners. IUCN, Gland, Switzerland and Cambridge, UK, p. 129.

Renaud, J.P., Rupe, C., Leclerc, D., 1994. Analyse des structures et diagnostic sylvicole dans une forêt à fonction de protection, Modes de gestion et stabilité. Revue Forestière Française 46 (6), 655-669.

Rey, F., Chauvin, C., 2001. Forest restoration in marly southern French Alps. In: Proceedings of the International Conference on "Forest Research: A Challenge for an Integrated European Approach". Thessaloniki, Greece, 27 August-1 September 2001, vol. I, pp. 365-369.

Rowe, J.S., Barnes, B.V., 1994. Geo-ecosystems and bio-ecosystems. Bull. Ecol. Soc. Am. 75, 40-41.

Schlaepfer, R., Iorgulescu, I., Glenz, C., 2002. Management of forested landscapes in mountain areas: an ecosystem-based approach. For. Policy Econ. 4 (2), 89-99.

Schönenberger, W., 2000. Silvicultural problems in subalpine forests in the Alps. In: Price, M.F., Butt, N (Eds.), Forests in Sustainable Mountain Development: A State of Knowledge Report for 2000. Task Force on Forests in Sustainable Mountain Development. CABI Publishing, pp. 197-203.

Schönenberger, W., 2001a. Trends in mountain forest management in Switzerland. Schweizerische Zeitschrift für Forstwesen 152 (4), 152-156. 
Schönenberger, W., 2001b. Cluster afforestation for creating diverse mountain structures - a review. For. Ecol. Manage. $145,121-128$.

Stand Montafon, 1990. Forest Inventory Results, Internal Report. Stand Montafon Forstfonds, Schruns, Austria.

Tilman, D., Downing, J.A., 1994. Biodiversity and stability in grasslands. Nature 367, 363-365.

Tilman, D., Knops, J., Wedin, D., Reich, P., Ritchie, M., Sieman, E., 1997. The influence of functional diversity and composition on ecosystem processes. Science 277, 1300-1302.

Troll, C., 1971. Landscape ecology (geoecology) and biogeocenology-a terminology study. Geoforum 8, 43-46.

UN-ECE/FAO, 2000. Forest Resources of Europe, CIS, North America, Australia, Japan and New Zealand (industrialised temperate/boreal countries). UN-ECE/FAO Contribution to the Global Forest Resources Assessment 2000. Geneva Timber and Forest Study Papers, vol. 17. United Nations, New York and Geneva.
Wasser, B., Frehner, M., 1996. Minimale Pflegesmassnahmen für Wälder mit Schutzfunktion. Wegleitung, Bundesamt für Umwelt, Wald und Landscahft (BUWAL), Bern, p. 122.

Weiss, G., 2000. Perception of risks in mountain forests. In: Price, M.F., Butt, N. (Eds.), Forests in Sustainable Mountain Development: A State of Knowledge Report for 2000. IUFRO Research Series 5. CABI Publishing, Wallingford, UK, pp. 359366.

Westra, L., 1996. Environmental integrity, racism and health. Sci. Total Environ. 184, 57-66.

White, P.S., Pickett, S.T.A., 1985. Natural disturbance and patch dynamics: an introduction. In: Picket, S.T.A., White, P.S. (Eds.), The Ecology of Natural Disturbance and Patch Dynamics. Academic Press, New York, pp. 3-13.

Woodley, S., Kay, J.J., Francis, G., 1993. Ecological Integrity and the Management of Ecosystems. St. Lucine Press, p. 212.

Yaffee, S.L., 1998. Three faces of ecosystem management. Conserv. Biol. 13 (4), 713-725. 